\title{
Tracking the Mediterranean Abyss
}

\author{
Simona Aracri ${ }^{1}$, Katrin Schroeder ${ }^{1}$, Jacopo Chiggiato ${ }^{1}$, Harry Bryden ${ }^{1,2}$, Elaine McDonagh ${ }^{2}$, \\ Simon Josey ${ }^{2}$, Yann Hello ${ }^{3}$, and Mireno Borghini ${ }^{1}$ \\ ${ }^{1}$ ISMAR-Istituto di Scienze Marine, Venice and La Spezia \\ ${ }^{2}$ NOC-National Oceanography Institute, Southampton \\ ${ }^{3}$ Géoazur-Valbonne, France \\ Correspondence to: Aracri Simona (simona.aracri@ve.ismar.cnr.it)
}

\begin{abstract}
The abyssal velocity of the Northern Current, in the north-western Mediterranean has been estimated using for the first time MERMAIDs, i.e. submarine drifting instruments that record seismic waves. In this study the Northern Current shows an intense activity even in deep layers of the water column. Through pseudo-eulerian statistics different components of the observed variability are analysed and described, revealing the turbulent nature of the Liguro-Provençal basin abyssal circulation.
\end{abstract}

\section{Keywords}

Western Mediterranean, Abyssal Circulation, Northern Current, lagrangian instruments, MERMAID

\section{Copyright statement}

The article is distributed under the Creative Commons Attribution 3.0 License. Unless otherwise stated, associated published material is distributed under the same licence

\section{Introduction}

The assessment of the abyssal contribution to the world ocean circulation represents one of the present challenges for oceanography. Despite the remarkable technological progresses of the last decades the deep ocean remains difficult to sample with adequate time and space resolution. Therefore it is still scarcely known and evaluating its contribution to the ocean dynamics is a tough task. The oceanographic peculiarity of the Mediterranean Sea (Fig. 1) lies in its typical oceanic processes, e.g. deep water formation (DWF) in the Gulf of Lion (GoL) (Marshall and Schott, 1999), in the Adriatic and the Aegean Sea (Schroeder et al. (2012); Malanotte-Rizzoli et al. (2013)), deep convection in the Ligurian Sea (Sparnocchia et al., 1995) and Levantine Basin (Georgopoulos et al., 1989), the thermohaline circulation, and its reduced time-scales. Thanks to these characteristics it constitutes the perfect observatory to understand the behaviour also of the world ocean. This study analyses data from the deep western Mediterranean Sea (WMED). The focus of this work is to study the deep circulation of the WMED and in particular 
Ocean Sci. Discuss., doi:10.5194/os-2016-65, 2016

Manuscript under review for journal Ocean Sci.

to observe the Northern Current (NC) evolution at depth by means of deep lagrangian floating devices, called MERMAIDs (Hello et al., 2011). The NC is a marked frontal structure (Astraldi et al., 1994) that involves the surface-intermediate layer and probably also the deep layer of the water column. It flows cyclonically along the southern European coast from the Ligurian Sea to the Alboran Sea. In the Ligurian Sea the NC is fed by the Eastern Corsica Current (ECC) and the Western Corsica Current (WCC) (Astraldi et al., 1994), see Fig. 1. Over the course of time dedicated experiments tried to depict the NC temporal and spatial variability (Taupier-Letage and Millot (1986); Conan and Millot (1995); Sammari et al. (1995); Alberola et al. (1995)), but only few refer to it as a characteristic involving the whole water column and therefore carrying deep waters (Millot, 1999). Most authors treat the NC as a surface-intermediate entity (Astraldi and Gasparini (1992); Robinson et al. (2001); Picco et al. (2010); Alvarez et al. (2013)). Others limit the NC influence to $1100 \mathrm{~m}$ depth (Taupier-Letage and Millot, 1986) and some touch on the possibility of the NC dragging along Western Mediterranean Deep Water (WMDW) (Conan and Millot, 1995) .

Lagrangian floats data are affected by uncertainties associated with positioning system, clock drift and unknown surface drift before submerging and after surfacing (Katsumata and Yoshinari, 2010). In previous experiments, e.g. SOFARGOS, deep floats such as RAFOS were localized at depth by triangulation using an array of moored acoustic sources, (Testor and Gascard (2003); Testor et al. (2005); Testor and Gascard (2006)). RAFOS accuracy for positioning was approximately $2 \mathrm{Km}$. Using ARGO floats or, as in the present work MERMAIDs, the positioning is done via satellite communication instead of an acoustic triangulation. Katsumata and Yoshinari (2010) infer that the sampling covariance of the drift mean velocity estimate is inversely proportional to the drifting time: the longer the float drifts at depth the smaller is going to be the error in velocity. In the case of ARGOs, the floats are programmed to surface approximately every 10 days or 5 days in the Mediterranean depending on the chosen sampling schedule, which renders an accurate estimation of the error and of its position difficult in most cases. MERMAIDs, in the present dataset, surface more often than ARGOs, i.e. on average every 4-5 days, so the uncertainty associated with their positioning remains an open question. MERMAIDs are programmed to ascend to the surface every 10 days, but since they are also designed to surface when they detect a seismic event, they can emerge more often, despite their default setting parameters. Differently from MERMAIDs, ARGOs have a prefixed parking depth, e.g. $350 \mathrm{~m}$ in the framework of MedArgo (Poulain et al., 2007), once every 10-5 days, they sink to a greater depth, i.e. $700 \mathrm{~m}$ or $2000 \mathrm{~m}$ and then they surface performing a CTD (Conductivity Temperature Depth) profile during the upcast (Menna and Poulain (2010); Poulain et al. (2007)). In the Mediterranean Sea ARGO floats have mostly been used to investigate intermediate currents (Menna and Poulain (2010); Poulain et al. (2007); Bosse et al. (2015)), in fact the $350 \mathrm{~m}$ target depth corresponds to the core depth of Levantine Intermediade Water (LIW). LIW is an intermediate water formed in the Levantine Basin, in the Eastern Mediterranean Sea. During the SOFARGOS project, RAFOS floats drifting depths were set to $350 \mathrm{~m}, 600 \mathrm{~m}$ and $1200 \mathrm{~m}$ in order to capture features of the behaviour of the entire water column. Testor and Gascard identified Submesoscale Coherent Vortices (SCV), and investigated their spatial distribution in the Algerian Basin (Testor et al., 2005) and in the north-western Mediterranean (Testor and Gascard, 2003), relating the occurrence of SCV with DWF (Testor and Gascard, 2006). SCV are long living anti-cyclonic vortices (in the northern hemisphere), which retain much of their core water mass and migrate far from their formation site (McWilliams, 1985). In Testor and Gascard (2003) the interaction between the SCV and the NC is mentioned: the newly formed deep water "bled" into the NC, which therefore influenced the spreading of the WMDW. 
Ocean Sci. Discuss., doi:10.5194/os-2016-65, 2016

Manuscript under review for journal Ocean Sci.

Published: 20 September 2016

(c) Author(s) 2016. CC-BY 3.0 License.

Discussions

(c) (i)

Although the RAFOS measurements aimed to sample and describe SCV they also provided some insight into the behaviour of the NC. After the measurements analysed in Testor and Gascard's studies in 2002 no more lagrangian deep measurements were reported in the NC. To our knowledge no other attempt were made to quantify the NC vertical influence or strength at depth.

From the MERMAID dataset, hereafter described and analysed, deep currents can be evinced.

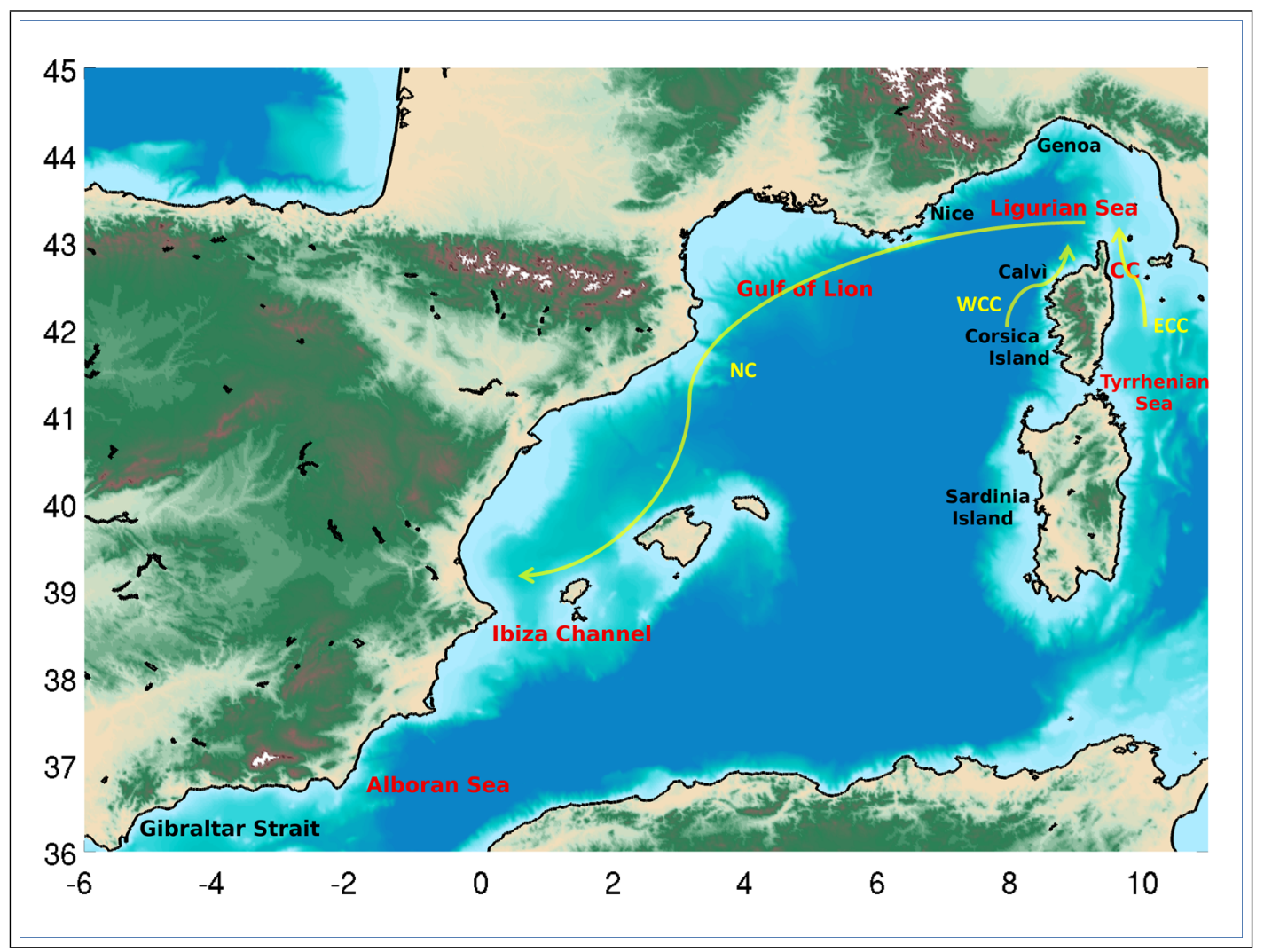

Figure 1. Ligurian Sea Map

\section{Data and Methods}

MERMAIDS are freely floating devices, deployed to capture underwater seismic waves (Sukhovich et al., 2015).

Seven Mermaid were deployed in the Ligurian Sea between December 2012 and July 2014: m17, m18, m30, m31, m32, m33, m35 (GLOBALSEIS, 2015). After the deployment the instrument stays at the surface to communicate its position, send its data and get new parameters for the following profile via Iridium satellite. Then air and oil are transferred from the external bladder into the float. At $50 \mathrm{~m}$ depth the transfer stops temporarily for further control and the profiler sinks until it reaches its parking depth where the acquisition starts (Table 1 summarizes mean parking depths, deployment and recovery times and coordinates for each MERMAID). The actual pressure at the parking depth is measured by the instrument. After about 4-5 days 
Ocean Sci. Discuss., doi:10.5194/os-2016-65, 2016

Manuscript under review for journal Ocean Sci.

Published: 20 September 2016

(c) Author(s) 2016. CC-BY 3.0 License.

\begin{tabular}{c|cccc}
\hline name & start & end & mean pd & start/end Lon $\mathrm{E}^{\circ} \mathrm{Lat}^{\circ}$ position \\
\hline $\mathrm{m} 17$ & $20-12-2012$ 11:27:31 & $20-07-201407: 21: 21$ & $916.4 \mathrm{~m}$ & $8,0643,20 /-0,7737,39$ \\
$\mathrm{~m} 18$ & $20-12-2012$ 11:29:41 & $21-10-201304: 57: 01$ & $871.3 \mathrm{~m}$ & $8,0643,20 / 3,6742,21$ \\
$\mathrm{~m} 30$ & $14-03-201412: 04: 51$ & $25-06-201407: 00: 11$ & $1606.4 \mathrm{~m}$ & $8,5243,80 / 6,0842,62$ \\
$\mathrm{~m} 31$ & $14-03-201411: 05: 11$ & $04-07-201506: 36: 01$ & $1476.3 \mathrm{~m}$ & $8,4043,75 / 4,1042,32$ \\
m32 & $14-03-201413: 22: 01$ & $02-07-201405: 58: 31$ & $1461.5 \mathrm{~m}$ & $8,5943,87 / 7,1643,28$ \\
m33 & $17-07-201411: 32: 21$ & $09-07-201521: 27: 11$ & $1513.2 \mathrm{~m}$ & $8,4043,23 / 8,2743,56$ \\
$\mathrm{~m} 35$ & $17-07-201413: 43: 31$ & $23-01-201506: 56: 21$ & $1498.1 \mathrm{~m}$ & $8,2643,45 / 6,9743,07$ \\
\hline
\end{tabular}

Table 1. Deployment and recovery times and mean parking depth for each MERMAID

(i.e. each time a seismic signal has been recorded by the instrument) the bladder is gradually filled up and the ascent phase begins. Depending on the water density the float can descent slower and the time it takes to reach the parking depth might vary. The position at $50 \mathrm{~m}$ depth is calculated assuming a linear drift evinced by two consequential GPS communications before the float starts its descent or finishes its ascent. The distance between the parking start and the parking end is divided by the time necessary for the float to move from one GPS point to the next in order to obtain a velocity for each segment of the trajectory. When the detection of a seismic wave forces the float to ascend, the MERMAID speed is set to the maximum in order to ascend as fast as possible to minimize the difference between its position at detection and the one at which it communicates with the GPS just after surfacing. This setting aims to minimize the error derived from the drifting that the float undergoes during its up-cast. When descending the float is set to optimize the electrical consumption by minimizing the pump and valve actions. For these reasons the ascent velocity is higher by a factor of $\sim 5$ than the descent velocity.

\section{Results}

All seven MERMAIDs missions deployed in the Liguro-Provençal basin are shown in Fig. 2 the operational depths can be found in the blue graph inserted over each map. It is assumed that the instrument descends vertically. The floats, e.g. m33 and $\mathrm{m} 35$, that were deployed away from the coast, between Nice and Calví remained trapped, at least at the beginning of their mission, in the middle of the cyclonic circulation, that characterize the north-western Mediterranean Sea. MERMAIDs that were deployed near the boundary of the NC immediately went westwards, following the main current (Fig. 2). Based on the mean velocities of $\mathrm{m} 17, \mathrm{~m} 30, \mathrm{~m} 31, \mathrm{~m} 32$, that drifted along the $\mathrm{NC}$, the estimate time to travel from the deployment location to the Ibiza Channel ranges from 385 to 875 days. The velocity variations with time of each float are represented in Fig. 3. 
Ocean Sci. Discuss., doi:10.5194/os-2016-65, 2016

Manuscript under review for journal Ocean Sci.

Published: 20 September 2016

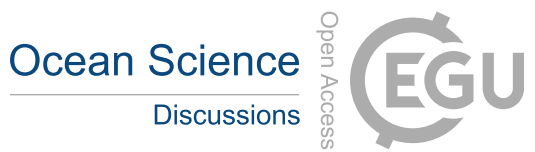

(c) Author(s) 2016. CC-BY 3.0 License.

(c) (1)
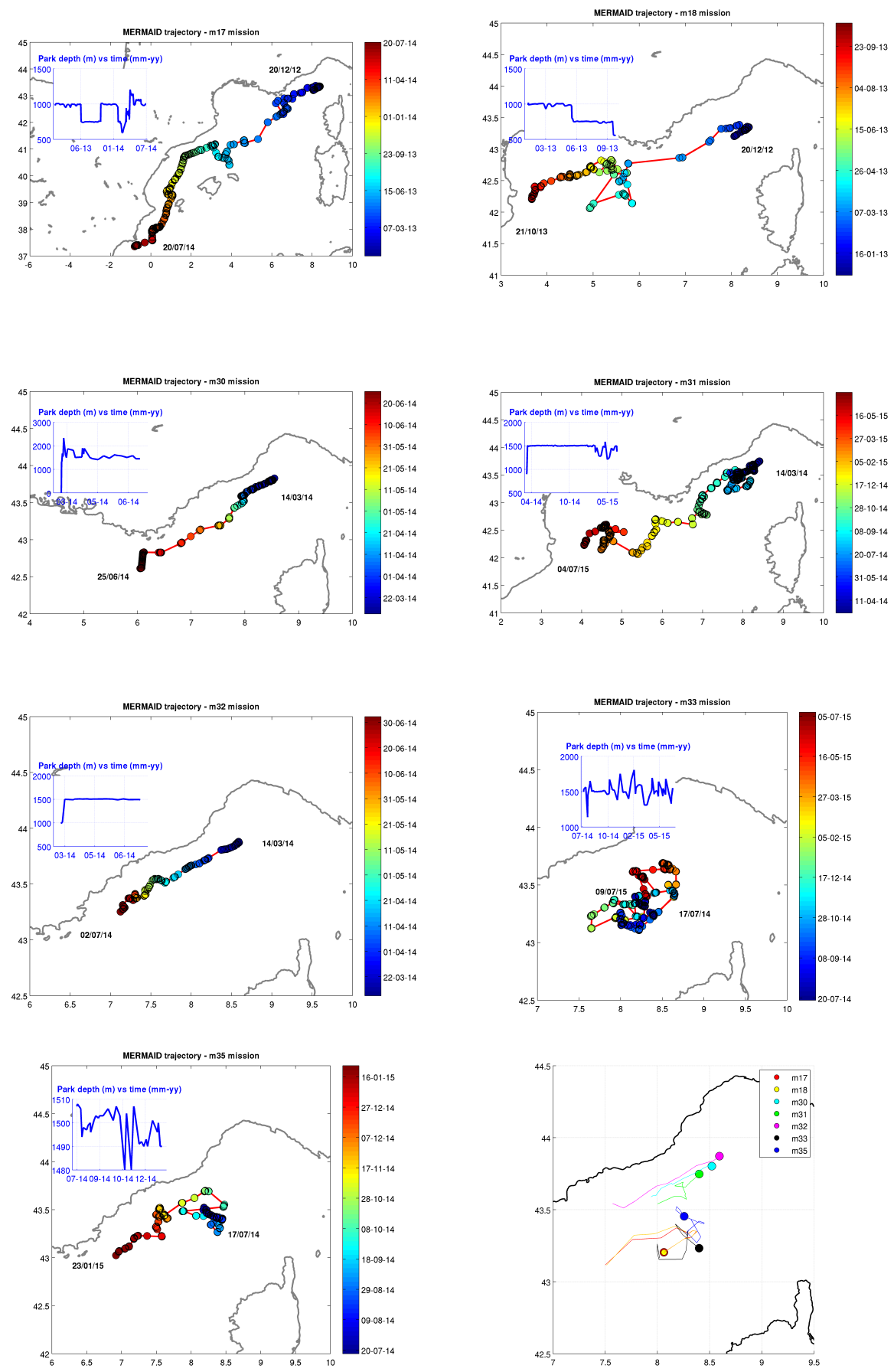

Figure 2. m17, m18, m30, m31, m32, m33, m35 trajectories. The colour represents time. On every plot starting and ending deployment days are displayed. The top left graph on each plot represents the parking depth against time for the MERMAID whose trajectory is displayed on the same plot. The bottom right plot represents deployment positions and first 15 dives position for each MERMAID. 
Ocean Sci. Discuss., doi:10.5194/os-2016-65, 2016

Manuscript under review for journal Ocean Sci.

Published: 20 September 2016
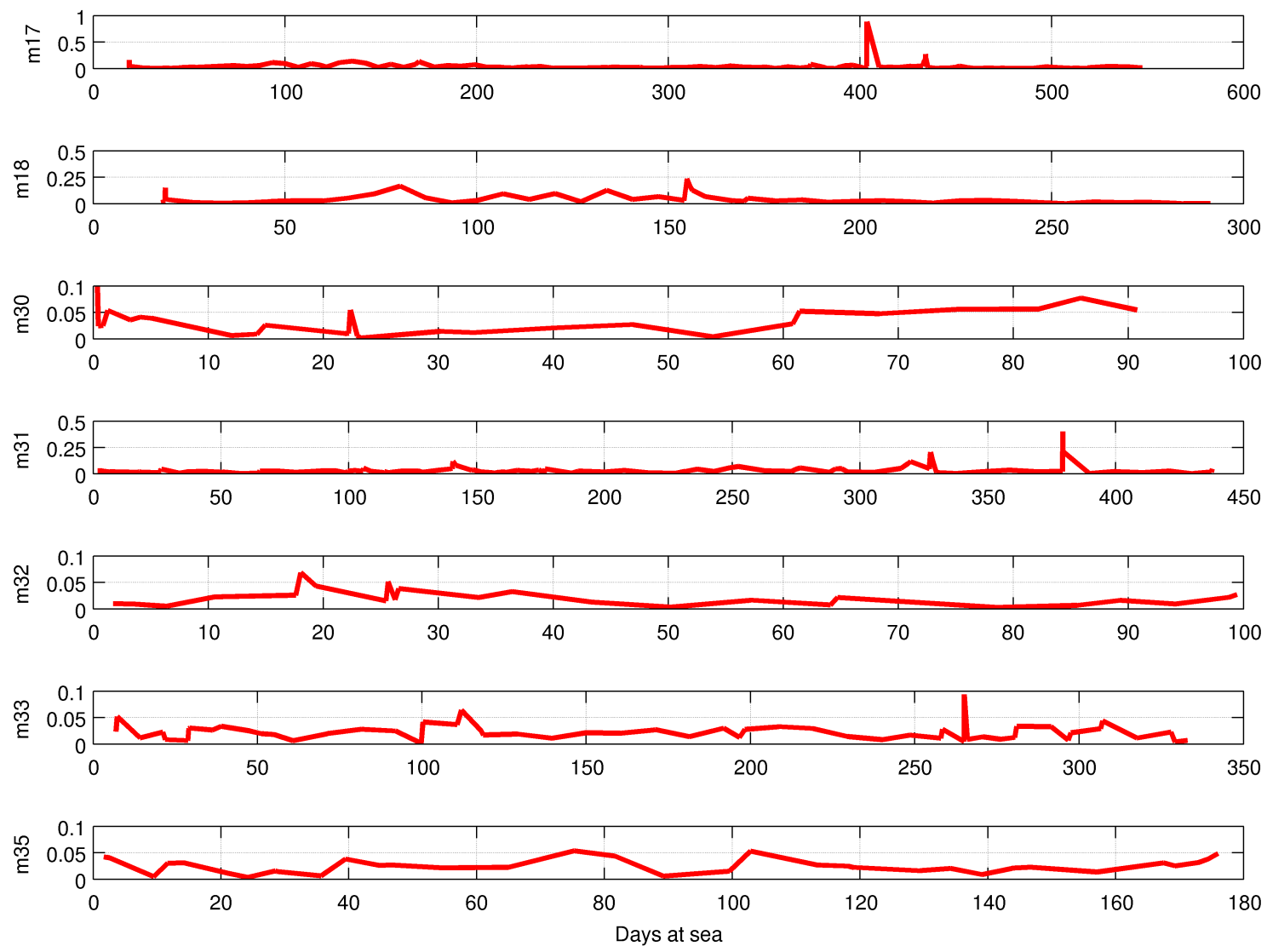

Figure 3. MERMAID velocities. The horizontal axes represents days at sea. Notice that the y axes have different ranges in order to better visualize the velocity of each MERMAID.

Pseudo-Eulerian statistics was computed from the MERMAID dataset. For this a bin size equal to 0.5 degrees was defined. Poulain (2001) suggests to use a minimum number of independent observations in order to discard bins with few observations, choosing 5 data per bin, as a practical trade-off between accuracy and geographical coverage. After examining the MERMAID geographical coverage the threshold number was set to 3 data per bin. Figure 4, top left panel, shows the entire dataset, with 5 all the data available per bin before setting the threshold. 
Ocean Sci. Discuss., doi:10.5194/os-2016-65, 2016

Manuscript under review for journal Ocean Sci.

Published: 20 September 2016

(C) Author(s) 2016. CC-BY 3.0 License.

(c) (1)
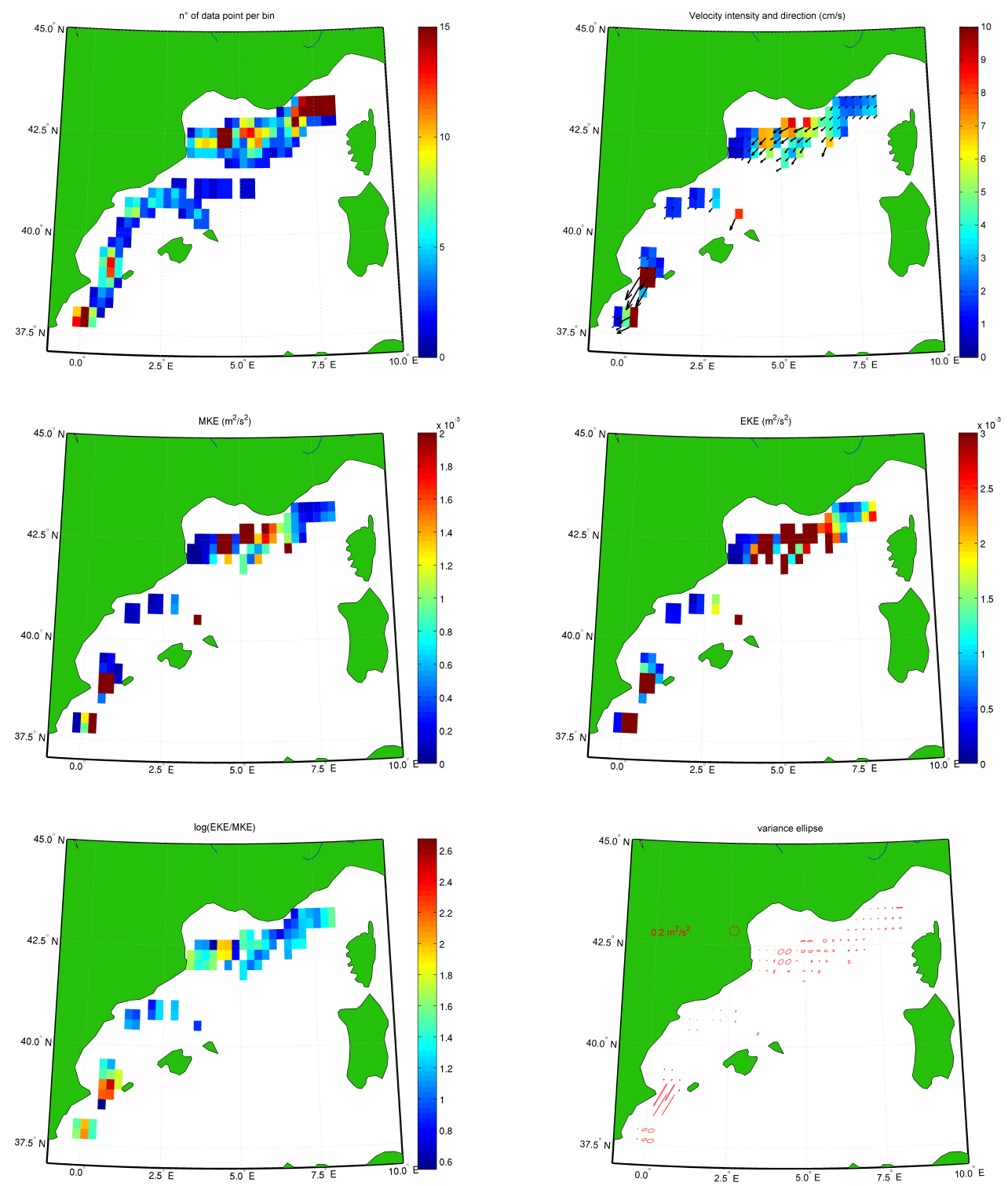

Figure 4. Pseudo-Eulerian statistics. Top left: number of data for bin before the threshold application. Top right: abyssal velocities and directions. Middle left: mean Kinetic Energy map. Middle right: eddy Kinetic Energy map. Bottom left: logarithmic EKE/MKE map. Bottom right: variance ellipses map.

Figure 4, top right panel, represents the abyssal flow along the NC, generally the current tends to follow the main stream westwards, but it is interesting to notice how sometimes MERMAIDs get trapped in a non linear fluctuation, especially in the GoL, e.g. m17, m31, m33, m35 (Fig. 2). Moreover the deep currents present peaks in the in the Ibiza Channel (800 m depth) and are enhanced in the GoL with respect to the Ligurian Sea, where they can reach $40.1 \mathrm{~cm} \mathrm{~s}^{-1}$ and $88.3 \mathrm{~cm} \mathrm{~s}^{-1}$ respectively. The 
Ocean Sci. Discuss., doi:10.5194/os-2016-65, 2016

Manuscript under review for journal Ocean Sci.

Published: 20 September 2016

(c) Author(s) 2016. CC-BY 3.0 License.

Ibiza Channel is known to be a monitoring 'choke point' in the western Mediterranean Sea. Its importance is due to the high variability in water transports (Heslop et al., 2012). In the GoL the intense activity in depth might be linked to the spreading of deep water formed in late winter, although not every year. As already observed for the surface by Poulain et al. (2012), the NC starts to spread and to flow more off shore after leaving the Ligurian coast. One could notice, in fact, that just before the GoL, the cross shore component of velocity increases, distancing the NC from the coast. The deep velocity observations suggest that the entire water column is involved in the cyclonic circulation of the Liguro-Provençal basin, differently from what was inferred by (Bethoux et al., 1982) and (Astraldi et al., 1994), who refer to the NC as a feature involving the surface and intermediate layer of the circulation. Following the formulation suggested in (Poulain, 2001) the Mean Kinetic Energy (MKE) per unit mass of the mean flow has been calculated for each bin, Fig. 4, middle panels.

10

$$
M K E=0.5 *\left(\bar{U}^{2}+\bar{V}^{2}\right)
$$

Where $\bar{U}$ and $\bar{V}$ are the mean zonal and meridional velocities averaged on each bin. In Fig. 4, middle left panel, the most active parts of the deep Liguro-Provençal basin as seen from the MERMAIDs are actually the GoL and the Ibiza Channel. Again the results are coherent with those obtained by (Poulain et al., 2012) for the surface circulation. In fact the Ligurian Sea presents low MKE values, which increase the more we move towards the GoL and off the French coast, then it remains quite low moving northwards of the Balearic Islands until it reaches again high values through the Ibiza Channel.

Eddy Kinetic Energy (EKE), Fig. 4, middle right panel, represents the mean kinetic energy, per unit mass of the flow fluctuations (Poulain, 2001) and it has been computed as:

Where $U^{\prime}=U-\bar{U}$ is the residual zonal velocity component and $V^{\prime}=V-\bar{V}$ is the residual meridional velocity. From observations we know that EKE dominates in the global ocean, because the ocean circulation is dynamic and turbulent (Delworth et al., 2012). In several points in Fig. 4, bottom left panel, the EKE is higher than the MKE, the fluctuations can reach 0.139 $\mathrm{m}^{2} \mathrm{~s}^{-2}$ in the Ibiza Channel while the MKE energy maximum is $0.015 \mathrm{~m}^{2} \mathrm{~s}^{-2}$. The behaviour of the EKE follows that of the MKE and the surface trend described in Poulain et al. (2012). In fact the EKE is largest in areas of strong currents (Delworth et al., 2012), i.e. the Gol and the Ibiza Channel in the area covered by MERMAIDs.

The variance ellipse has been computed, Fig. 4, bottom right panel, following the formulation in (Emery and Thomson, 2001). The variance ellipse axes and rotation are functions of the variance and the covariance of the two velocity components. The covariance ellipses are therefore orientated in the direction of the main current, Fig. 4, bottom right panel. Apart from the above mentioned intense westward flow off the Ligurian coast, close to the GoL and in the Ibiza Channel, we can notice that the central GoL and after the Ibiza Channel the ellipses are more rounded, This can be linked in the GoL to the spreading of the newly formed Western Mediterranean Deep Water (nWMDW) towards the interior of the basin. South of the Ibiza Channel the circulation might be influenced by the presence of a cyclonic eddy (Heslop et al., 2012) that deviates the recently entered Atlantic Water (AW), forcing it to skew towards the center of the western Mediterranean basin. 
Ocean Sci. Discuss., doi:10.5194/os-2016-65, 2016

Manuscript under review for journal Ocean Sci.

Published: 20 September 2016

(c) Author(s) 2016. CC-BY 3.0 License.

Figure 4, bottom left panel, shows the logarithm of the ratio between EKE and MKE. This view gives information about the distribution of the energy in the observed currents (Poulain, 2001). In areas where the $\log (\mathrm{EKE} / \mathrm{MKE})$ is higher the current fluctuation kinetic energy is higher than that of the mean flow, from Fig. 4, bottom left panel, these areas are the western Ligurian Gulf, the GoL, the Ibiza Channel and the area just north of the Alboran Sea. The logarithm is close to zero when the

5 two kinetic components are close one to each other, this happens mostly towards the interior of the basin and in the NC branch between the Balearic Islands and the main land.

\section{Discussion and Conclusion}

MERMAIDs mostly dived deeper than $800 \mathrm{~m}$, following LIW's bottom layer and WMDW (Schroeder et al., 2010). The instruments tended to follow the deep NC, suggesting, despite what was inferred by (Bethoux et al., 1982) and (Astraldi et al., 1994), that the NC involves the whole water column. MERMAID data and analysis presented in this work support TaupierLetage and Millot (1986)'s observations: even at $1100 \mathrm{~m}$ at depth the NC reveals a certain activity. The data also endorse Conan and Millot (1995)'s hypothesis about the NC transporting LIW, Winter Intermediate Water (WIW) and WMDW. It was interesting to notice some eddy features even at MERMAID parking depths. From several MERMAID paths and from calculated abyssal velocities the deep NC close to the Ligurian Gulf results weaker with respect to GoL and Ibiza Channel and can present meanders. Figure 2 shows how MERMAID m31 and m35 got trapped, at least at the beginning of the deployment, in the central cyclone. In particular MERMAID m33 remained in the central cyclone, at approximately 1500 m, for at least one year. During SOFARGOS experiment, RAFOS remained at sea for five-seven months and they floated in a depth range from $350 \mathrm{~m}$ to $1450 \mathrm{~m}$ detecting several cyclones and anti-cyclones in the north-western Mediterranean (Testor and Gascard, 2006). The m33 path provides new informations about the persistence and the depth of deep NC meanders. The abyssal NC presents less vortices the closer it gets to the Balearic Islands. Given the average velocities of $\mathrm{m} 17, \mathrm{~m} 30, \mathrm{~m} 31, \mathrm{~m} 32$, the time necessary to flow from the Ligurian Gulf to the Ibiza Channel at 900-1600 m depth ranges from 385 to 875 days; it took 575 days to $\mathrm{m} 17$, the only float that reached the Ibiza Channel. An intense activity is evident even at depth, from the pseudo-eulerian study. The GoL and the adjacent Ligurian Sea, together with the Ibiza Channel appear to have a key role in the abyssal circulation of the basin. Most of the kinetic energy observed in these areas result to be ascribable to the EKE, being, then, due to turbulent and dynamic circulation. A deep sea dataset is rare, extremely valuable and demanding, hence the MERMAID dataset, although small, adds a fundamental piece of information to the present knowledge of the deep western Mediterranean Sea.

\section{Data availability}

All the data used in this paper are freely available at ftp:/geoazur.unice.fr/pub/outgoing/mermaid/events/.

\section{Competing interests}

The authors declare that they have no conflict of interest. 
Ocean Sci. Discuss., doi:10.5194/os-2016-65, 2016

Manuscript under review for journal Ocean Sci.

Published: 20 September 2016

(c) Author(s) 2016. CC-BY 3.0 License.

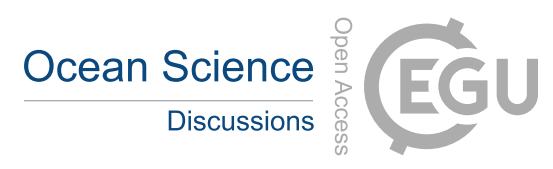

(c) (i)

Acknowledgements. This work is supported by the RITMARE Italian flagship project, that sponsors Simona Aracri's research. The authors are deeply grateful to the technical staff and crew, on land and on board, that designed and deployed MERMAID floaters. 
Ocean Sci. Discuss., doi:10.5194/os-2016-65, 2016

Manuscript under review for journal Ocean Sci.

Published: 20 September 2016

(c) Author(s) 2016. CC-BY 3.0 License.

\section{References}

Alberola, C., Millot, C., and Font, J.: On the seasonal and mesoscale variabilities of the Northern Current during the PRIMO-0 experiment in the western Mediterranean Sea, Oceanologica Acta, 18, 163-192, doi:0399-1784, http://archimer.ifremer.fr/doc/00096/20770/, 1995.

Alvarez, a., Chiggiato, J., and Schroeder, K.: Mapping sub-surface geostrophic currents from altimetry and a fleet of gliders, Deep Sea Research Part I: Oceanographic Research Papers, 74, 115-129, doi:10.1016/j.dsr.2012.10.014, http://linkinghub.elsevier.com/retrieve/pii/ S0967063712002221, 2013.

Astraldi, M. and Gasparini, G. P.: The seasonal characteristics of the circulation in the north Mediterranean basin and their relationship with the atmospheric-climatic conditions, Journal of Geophysical Research, 97, 9531-9540, 1992.

Astraldi, M., Gasparini, G. P., and Sparnocchia, S.: The Seasonal and Interannual Variability in the Ligurian-Provencal Basin, Coast. Estuar. Stud., 46, 93-113, 1994.

Bethoux, J., Prieur, L., and Nyffeler, F.: The Water Circulation in the North-Western Mediterranean Sea, its Relations with Wind and Atmospheric Pressure, Elsevier, Amsterdam, 1982.

Bosse, A., Testor, P., Mortier, L., Prieur, L., Taillandier, V., d'Ortenzio, F., and Coppola, L.: Spreading of Levantine Intermediate Waters by submesoscale coherent vortices in the northwestern Mediterranean Sea as observed with gliders, Journal of Geophysical Research: Oceans, 120, 1599-1622, doi:10.1002/2014JC010263, http://dx.doi.org/10.1002/2014JC010263, 2015.

Conan, P. and Millot, C.: Variability of the northern current off Marseilles, western Mediterranean Sea, from February to June 1992, Oceanologica Acta, 18, 193-205, 1995.

Delworth, T. L., Rosati, A., Anderson, W., Adcroft, A. J., Balaji, V., Benson, R., Dixon, K., Griffies, S. M., Lee, H.-C., Pacanowski, R. C., Vecchi, G. A., Wittenberg, A. T., Zeng, F., and Zhang, R.: Simulated Climate and Climate Change in the GFDL CM2.5 High-Resolution Coupled Climate Model, Journal of Climate, 25, 2755-2781, doi:10.1175/JCLI-D-11-00316.1, 2012.

Emery, W. and Thomson, R.: Data Analysis Methods in Physical Oceanography, Pergamon, Oxford, UK, 2001.

Georgopoulos, D., Theocharis, A., and Zodiatis, G.: Intermediate water formation in the Cretan Sea (South Aegean Sea)., Oceanologica Acta, 12, 353-359, doi:0399-1784/89/04 353 7, http://archimer.ifremer.fr/doc/00106/21732/, 1989.

GLOBALSEIS: MERMAID data, https://www.geoazur.fr/GLOBALSEIS/Data.html, 2015.

Hello, Y., Ogé, A., Sukhovich, A., and Nolet, G.: Modern mermaids: New floats image the deep Earth, Eos, Transactions American Geophysical Union, 92, 337-338, doi:10.1029/2011EO400001, http://dx.doi.org/10.1029/2011EO400001, 2011.

Heslop, E., Ruiz, S., Allen, J., López-Jurado, J., Renault, L., and Tintoré, J.: Autonomous underwater gliders monitoring variability at "choke points" in our ocean system: A case study in the Western Mediterranean Sea, Geophysical Research Letters, 39, L20 604, doi:10.1029/2012GL053717, 2012.

Katsumata, K. and Yoshinari, H.: Uncertainties in global mapping of Argo drift data at the parking level, Journal of Oceanography, 66, 553-569, doi:10.1007/s10872-010-0046-4, http://dx.doi.org/10.1007/s10872-010-0046-4, 2010.

Malanotte-Rizzoli, P., Artale, V., Borzelli-Eusebi, G. L., Brenner, S., Civitarese, G., Crise, A.and Font, J., Gacic, M., Kress, N., Marullo, S., Ozsoy, E., Ribera d'Alcalà, M., Roether, W., Schroeder, K., Sofianos, S., Tanhua, T.and Theocharis, A., Alvarez, M., Ashkenazy, Y., Bergamasco, A.and Cardin, V., Carniel, S., D’Ortenzio, F., Garcia-Ladona, E., Garcia-Lafuente, J. M., Gogou, A., Gregoire, M., Hainbucher, D., Kontoyannis, H., Kovacevic, V., Krasakapoulou, E., Krokos, G., Incarbona, A., Mazzocchi, M. G., Orlic, M., Pascual, A., Poulain, P.-M., Rubino, A., Siokou-Frangou, J., Souvermezoglou, E., Sprovieri, M., Taupier-Letage, I., Tintoré, J., and Triantafyllou, G.: 
Ocean Sci. Discuss., doi:10.5194/os-2016-65, 2016

Manuscript under review for journal Ocean Sci.

Published: 20 September 2016

(c) Author(s) 2016. CC-BY 3.0 License.

Physical forcing and physical/biochemical variability of the Mediterranean Sea: a review of unresolved issues and directions for future research, Ocean Science, 10, 281-322, doi:10.5194/os-10-281-2014, 2013.

Marshall, J. and Schott, F.: Open-Ocean Convection: observations, theory and models, Reviews of Geophysics, 37, 1-64, doi:10.1029/98RG02739, 1999.

5 McWilliams, J. C.: Submesoscale, coherent vortices in the ocean, Reviews of Geophysics, 23, 165-182, doi:10.1029/RG023i002p00165, http://dx.doi.org/10.1029/RG023i002p00165, 1985.

Menna, M. and Poulain, P.: Mediterranean intermediate circulation estimated from Argo data in 2003-2010, Ocean Science, 6, 331-343, https: //www.scopus.com/inward/record.url?eid=2-s2.0-77749295090\&partnerID=40\&md5=54c74a3ff6f5c6200e59a2eeb7a86d94, cited By 0, 2010.

Millot, C.: Circulation in the Western Mediterranean Sea, Journal of Marine Systems, 20, 423-442, doi:10.1016/S0924-7963(98)00078-5, http://linkinghub.elsevier.com/retrieve/pii/S0924796398000785, 1999.

Picco, P., Cappelletti, A., Sparnocchia, S., Schiano, M. E., Pensieri, S., and Bozzano, R.: Upper layer current variability in the Central Ligurian Sea, Ocean Science, 6, 445-475, doi:10.5194/os-6-825-2010, http://www.ocean-sci.net/6/825/2010/http://www.ocean-sci-discuss. net/7/445/2010/, 2010 .

Poulain, P.-M.: Adriatic Sea surface circulation as derived from drifter data between 1990 and 1999, Journal of Marine Systems, 29, 3-32, doi:10.1016/S0924-7963(01)00007-0, 2001.

Poulain, P.-M., Barbanti, R., Font, J., Cruzado, A., Millot, C., Gertman, I., Griffa, A., Molcard, A., Rupolo, V., Le Bras, S., and Petit de la Villeon, L.: MedArgo: a drifting profiler program in the Mediterranean Sea, Ocean Science, 3, 379-395, doi:10.5194/os-3-379-2007, http://www.ocean-sci.net/3/379/2007/, 2007.

Poulain, P.-M., Gerin, R., Rixen, M., Zanasca, P., Teixeira, J., Griffa, A., Molcard, A., de Marte, M., and Pinardi, N.: Aspects of the surface circulation in the Liguro-Provençal basin and Gulf of Lion as observed by satellite-tracked drifters (2007-2009), Bollettino di Geofisica Teorica ed Applicata, pp. 261-279, 2012.

Robinson, A. R., Leslie, W. G., Theocharis, A., and Lascaratos, A.: Mediterranean sea circulation, Ocean Currents: A Derivative of the Encyclopedia of Ocean Sciences, pp. 1689-1705, 2001.

Sammari, C., Millot, C., and Prieur, L.: Aspects of the seasonal and mesoscale variabilities of the Northern Current in the western Mediterranean Sea inferred from the PROLIG-2 and PROS-6 experiments, Deep-Sea Research Part I, 42, 893-917, doi:10.1016/09670637(95)00031-Z, 1995.

Schroeder, K., Josey, S. A., Herrmann, M., Grignon, L., Gasparini, G. P., and Bryden, H. L.: Abrupt warming and salting of the Western Mediterranean Deep Water after 2005: Atmospheric forcings and lateral advection, J. Geophys. Res., 115, C08 029, doi:10.1029/2009JC005749, http://doi.wiley.com/10.1029/2009JC005749, 2010.

Schroeder, K., Garcìa-Lafuente, J., Josey, S. A., Artale, V., Nardelli, B. B., Carrillo, A., Gačić, M., Gasparini, G. P., Herrmann, M., Ludwig, W., Millot, C., Özsoy, E., Pisacane, G., Sánchez-Garrido, J. C., Sannino, G., Santoleri, R., Somot, S., Struglia, M., Stanev, E., TaupierLetage, I., Tsimplis, M. N., Vargas-Yáñez, M., Zervakis, V., and Zodiatis, G.: Circulation of the Mediterranean Sea and its Variability, Elsevier, doi:10.1016/B978-0-12-416042-2.00003-3, http://www.sciencedirect.com/science/article/pii/B9780124160422000033, 2012.

Sparnocchia, S., Picco, P., Manzella, G. M. R., Ribotti, A., Copello, S., and Brasey, P.: Intermediate water formation in the Ligurian Sea, Oceanologica Acta, 18, 151-162, http://archimer.ifremer.fr/doc/00096/20769/, 1995.

Sukhovich, A., Bonnieux, S., Hello, Y., Irisson, J.-O., Simons, F. J., and Nolet, G.: Seismic monitoring in the oceans by autonomous floats, Nature Communications, 6, 8027, doi:10.1038/ncomms9027, http://dx.doi.org/10.1038/ncomms9027, 2015. 
Ocean Sci. Discuss., doi:10.5194/os-2016-65, 2016

Manuscript under review for journal Ocean Sci.

Published: 20 September 2016

(c) Author(s) 2016. CC-BY 3.0 License.

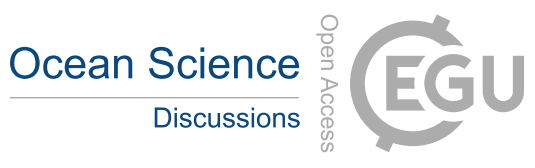

(c) (i)

Taupier-Letage, I. and Millot, C.: General hydrodynamical features in the Ligurian Sea inferred from the Dyomé experiment, Oceanologica Acta, 9, 119-131, 1986.

Testor, P. and Gascard, J.: Large-scale spreading of deep waters in the Western Mediterranean Sea by submesoscale coherent eddies, Journal of physical oceanography, 33, 75-87, 2003.

5 Testor, P. and Gascard, J.-C.: Post-convection spreading phase in the Northwestern Mediterranean Sea, Deep Sea Research Part I: Oceanographic Research Papers, 53, 869-893, doi:http://dx.doi.org/10.1016/j.dsr.2006.02.004, http://www.sciencedirect.com/science/article/pii/ S0967063706000550, 2006.

Testor, P., Send, U., Gascard, J.-C., Millot, C., Taupier-Letage, I., and Béranger, K.: The mean circulation of the southwestern Mediterranean Sea: Algerian Gyres, Journal of Geophysical Research: Oceans, 110, C11 017, doi:10.1029/2004JC002861, http://dx.doi.org/10.1029/ 2004JC002861, 2005. 